\title{
Marlowe's Presentation of Edward the Second as a Homosexual
} Text

\author{
Arka Pramanick \\ M.A, The University Of Burdwan, Govt. Assistant Teacher Of Engish In Chotosarsa Junior High School, \\ India
}

\begin{abstract}
My project is directed towards an exploration of how homophobic theme in Edward The Second dominates the story structure of the play and how Marlowe has transgressed the church domination of sixteenth century by representing such a violent theme like homophobia. To do so, I have made emphasis on the way the characters interact with one another and create a particular relational network on the stage. This interaction occurs mostly by means of their language, that is, by the way they speak to each other in the whole play.
\end{abstract}

Keywords: homosexuality,sodomy,friendship, pleasure politics, iableaux vivants, voluptas aerumnosa,love, gender.

"Gay" or 'homosexuality', these terms are relatively modern inventions. They did not exist in the middle ages. Instead, medieval writers used the term 'sodomy' to cover a multitude of what were considered to be 'sins'. This term generally had a much broader definition than the one we use today. For example, it could include heterosexual anal intercourse and oral sex as well as various homosexual acts. Societal attitudes towards same-sex relationships have varied over time and place. In cultures influenced by Abrahamic religions, the law and the church established sodomy as a transgression against divine law or a crime against nature. The condemnation of anal sex between males, however, predates Christian belief. It was frequent in ancient Greece; "unnatural" can be traced back to Plato. Many historical figures, including Socrates, Lord Byron, Edward The Second, and Hadrian, have had terms such as gay or bisexual applied to them; some scholars, such as Michel Foucault, have regarded this as risking the anachronistic introduction of a contemporary construction of sexuality foreign to their times, though others challenge this. Therefore Christopher Marlowe's Edward The Second makes one point absolutely clear, it's that homophobia is certainly nothing new. Yet nowhere in Marlowe's Edward The Second is there actually any mention of the terms Sodomy or homosexuality.

Rather Edward The Second begins with the concept of intense friendship between two major characters , king Edward and Gaveston. Yet scholars are of different view about friendship. While defining the nature of friendship Aristotle once said "What is a friend? A single soul dwelling in two bodies" .[2] Even Plato argued the importance of friendship in his formation of many political concepts and epitomised it as an essential virtue. But not all friendship seems virtuous and therefore Aristotle says there are three types of friendship. The first is of a higher friendship, which is based on virtue and has nothing to do with politics. It is a friendship based on two virtuous men. Secondly, the friendship grounded on utility and usefulness and this is political friendship. Third, and on the lower level, friendship grounded on pleasure i.e. looking for pleasure among young people. While the Kings Edward II and Gaveston seem to appear in the second category because of their political friendship, they necessarily fall into the third category of pleasure due to their natural inclination towards homosexual pleasures.

Some scholars are of opinion that the origin of this homosexuality can be traced clearly if we discuss the historical perspective of the play. J.Cady says-

“ The reign of Edward the second, the king of England (1307 to 1327) has been considered to be one of the gloomiest periods in British history. Historians refer to him as an unworthy son of Edward I. But historians also claim the lack of proper upbringing causes it."[1]

Actually Edward II was born with certain inherent character traits that dominate his life and actions throughout his life. He had the misfortune to be the son of a dominating father who was also an autocratic king. The young Edward had the misfortune to lose his mother when he was quite young and was thus deprived of the love and care of his mother which too stunted his growth. He lacked both maternal and paternal love and this made him seek for love elsewhere. Hence, his infatuation for Gaveston increased as he was the only person who loved him. As Marlowe's work is, overall, historically accurate, it comes as a surprise to the theatergoer not familiar with English history that a monarch's homosexuality led to such strife with his nobles that the king's lover was murdered, and, eventually, the king himself deposed and slain in a brutally grotesque bit of violence parodying a homosexual act of love. Therefore this theme of homosexuality could constitute a social threat in 
Marlowe's England when it was combined with the issues of status transgression. The notable trial of Mervin Touchet, second Earl of Castlehaven, reveals a pervasive judicial anxiety over the combination of open male homoeroticism and the failure to uphold aristocratic ideals. Castlehaven was executed in 1631 on two counts of sodomy and one abetting rape. Inspite of all these, it is also somewhat surprising that Marlowe could deal with the topic so frankly. Edward The Second deals with the king's homosexual relationship much more openly than, say, Tennessee Williams' presentation of Sebastian Venable's homosexuality in Suddenly Last Summer on the American stage.

Now We should directly come to the the text and try to expose the homoerotic mechanism that Marlow has quite successfully used in Edward II. Marlowe prepares the Elizabethan audience for a homosexual union between Edward and his favourite Gaveston, from the very opening scene delivering a promise to share the kingdom with thy dearest friend ( $I, \mathrm{i}, 2)$, an intense monologue describing the reciprocal relationship with each other :

"What greater bliss can hap to Gaveston

Than live and be the favourite of a King!

Sweet prince, I come! These, these thy amorous lines

Might have enforced me to have swum from France,

And, like Leander, gasped upon the sand,

So thou wouldst smile, and take me in thine arms." (I. i. 4-9) [2]

We thereafter see how Gaveston who is delighted to be recalled to England on Edward-I's death and makes it plain that he has no love for the London to which he has returned. It is his weakness for Edward that compels him to return to that city:

"Not that I love the city or the men,

But that it harbours him I hold so dear,

The king,upon whose bosom let me die,

And with the world be still at enemity." (I. i. 12-15)

While returning to home ground Gaveston encounters three 'Poor Men' who wish to enter his service: he behaves churlishly until he reminds himself that they may have their uses. The speech which follows his dismissal of the poor men then builds the contrasting fantasy of homoerotic pleasure :

"I must have wanton poets, pleasant wits,

Musicians, that with touching of a string

May draw the pliant King which way I please.

Music and poetry is his delight;

Therefore I'll have Italian masks by night,

Sweet speeches, comedies, and pleasing shows;

And in the day, when he shall walk abroad,

Like sylvan nymphs my pages shall be clad;

My men, like satyrs grazing on the lawns,

Shall with their goat feet dance the antic hay.

Sometime a lovely boy in Dian's shape,

With hair that gilds the water as it glides,

Crownets of pearl about his naked arms,

And in his sportful hands an olive tree,

To hide those parts which men delight to see, 
Shall bathe him in a spring; and there, hard by,

One like Actæon, peeping through the grove,

Shall by the angry goddess be transformed,

And running in the likeness of an hart,

By yelping hounds pulled down, shall seem to die:

Such things as these best please his majesty,” (I. i. 51-71)

The speech projects an idealized sensuality and a paganised paradise mixed with a formalized homosexuality. It is interesting that the idea of play is conveyed by the word 'frolic' three times early in the drama to highten the sense of frivolity. The speech combines in an erotic unity the Iableaux vivants and the royal core of the speech is the story of Actaeon, which has a retrospective relevance to the fate of Edward. The young noble torn to bits by hounds, after being chased into a stag for having seen Diana bathing naked, is emblematic of the King's excess. Edward indirectly applies the legend when, in his forced abdiction scene, he compares himself to the royal stag:

“... The forest deer, being struc,

Runs to an herb that closet up the wounds" (V. i. 9-10)

In Gaveston's speech the legend lends itself to a moral application that would not escape the subtler interpreters in the Elizabethan audience. Whitney gives a moral interpretation to the story and cites Ovid, the classical source on which Marlowe probably drew directly. Whitney draws the moral that obviously applies to Gaveston's sensual relishing of the scene in his mind's eye. After his describing the device - the stag-man is pictured being rent by hounds in a forest with a house in the background- the motto voluptas aerumnosa', is developed:

"By which is ment, That those whoe do pursue

Theire fancies fonde, and things unlawfull craue,

Like brutish beastes appeare unto the viewe,

And shall at lengthe, Actaeons guerdon haue;

And as his houndes, soe theire affections base,

Shall them deuore,and all their deedes deface." [3]

Gaveston shows here the dramatic outlines of the Vice, but not strictly as tempter. The temptation has taken place long before the play begins, when Edward and Gaveston spent their boyhood together in France. Gaveston is rather the embodiment of the weakness of the king. After Gaveston's death, his role is assumed by Spencer Junior and Baldock, who again illustrate Edward's inability to tell appearance from reality.

The theme of homoerotism can be found again in the long cherished reunion scene of Edward and Gaveston, and the exchanges between the two are unrestrained. The following dialogue is an apt example for this relationship:

"EDWARD. What, Gaveston, welcome, kiss not my hand;

Embrace me, Gaveston, as I do thee.

Why shouldst thou kneel? Know'st thou not who I am?

Thy friend, thyself, another Gaveston.

Not Hylas was more mourned of Hercules

Than thou hast been of me since thy exile.

GAVESTON. And, since I went from hence, no soul in hell

Hath felt more torment than poor Gaveston. 
EDWARD. I know it. Brother, welcome home my friend.

Now let the treacherous Mortimers conspire,

And that high-minded Earl of Lancaster:

I have my wish, in that I joy thy sight;

And sooner shall the sea o'erwhelm my land

Than bear the ship that shall transport thee hence.

I here create thee Lord High Chamberlain,

Chief Secretary to the state and me,

Earl of Cornwall, King and Lord of Man." (I.i. 140-156)

And therefore, the elation of Gaveston on hearing all that the king has said finds expressing in inflated rhetoric:

"It shall suffice me to enjoy your love,

Which whiles I have, I think myself as great

As Caesar riding in the Roman street

With captive kings at his triumphant car." (I.i. 171-174)

The result of this unbounded joy at meeting after a long time is the commission of foolish and arbitrary act, imprisonment of the Bishop of Coventry and bestowing of his wealth and property on Gaveston. No doubt both of them behave extremely beyond the interest of the people of England. This is a part of the temptation of Edward II. Both the Bishop and Kent warn against this temptation and are unheeded.

The scene of sensuous reunion of Aci-I,sc.-i ,I believe, reminds us of any romantic film where anxious lover meets his/her partner after a long time and expresses all sorts of unrestrained emotional frivolity. Of course, the King's brother, the Earl of Kent, protests against such frivolity by saying :

"Brother, the least of these may well suffice

For one of greater birth than Gaveston."

But Edward stops him with his high erotic tones that describes nothing but the great depth of Edward's love for Gaveston:

"Cease, brother, for I cannot brook these words.

Thy worth, sweet friend, is far above my gifts:

Therefore, to equal it, receive my heart." (I.i. 157-59)

Apart from this, Edward gave even his Queen Isabella's presents from her father to Gaveston and ignored her for the sake of his favourite. He is mainly interested in Gaveston rather than any matter of the country. Instead of winning the support and co-operation of the barons for good and welfare of the kingdom, he will have Gaveston even if it means armed conflict with the barons.

In this connection, it is a fact that Queen Isabella has become unable to bear to see the excessive interest of the king in the love Gaveston and expresses the statement in sorrowful discontentment:

"For now my lord the King regards me not,

But dotes upon the love of Gaveston.

He claps his cheeks and hangs about his neck,

Smiles in his face and whispers in his ears,

And when I come he frowns, as who should say,

"Go wither thou wilt, seeing I have Gaveston" (I.ii. 49-54)

Isabella's grief at Edward's desertion of her naturally strengthens the audience's felling against him. At once, however, we have a hint of a special relationship between the Queen and Mortimer. Her last words here are :

"Farewell, sweet Mortimer; and for my sake,

Forbear to levy arms against the king." (II. i. 81-2)

We see her kindness for him ('sweet Mortimer') and her belief in having some power over him('for my sake'). Although there is no hint of any direct infidelity on Isabella's part through out the text, yet she makes free use of her power over Mortimer, and Marlowe thus prepare us for a closer relationship between them. This technique also, I feel, provides the audience the reasons for the neglecting attitude of Edward towards her wife and his deep love for Gaveston who, atleast Edward belives, doesn't intrigue him by any means. This attitude is quite clear when Mortimer asks:

"Why should you love him whom the world hats so?” (I.iv. 76)

and Edward replies:

"Because he loves me more than all the world" (I.iv.77)

We know what Gaveston's love is worth, yet this naïve utterance of Edward is enough to put us, for the moment, on his side. He becomes an emblem of the human need for love, the very human joy when love seems offered.

However, as the play progresses we see, as much as Gaveston pleases the king, he finds scant favour from the king's nobles, who are soon clamouring for Gaveston's exile. For example, in Act I, Scene IV, Mortimer Senior asks patience from his nephew, telling him to "let [Edward] without controlment have his will. 
The mightiest kings have had their minions." Here Mortimer Junior is acknowledging Edward's acts of homosexuality with indifference, almost with normalcy. By referencing the other mighty kings who have performed in homosexual acts he is actually excusing and overlooking Edward's homosexuality. Mortimer Junior's response to his uncle further emphasizes this point: "Uncle, his wanton humor grieves not me,/ But this I scorn - that one so basely born /Should by his Sovereign's favor grow so pert." Mortimer Junior is plainly saying that Edward's homosexuality does not bother him, but it is the partner which Edward has chosen which angers Mortimer Junior so greatly. Finally Edward is forced to agree to this and banishes Gaveston to Ireland, but Isabella of France, the Queen, who still hopes for his favour, persuades Mortimer, to argue for his recall, though only so that he may be more conveniently murdered. The nobles accordingly soon find an excuse to turn on Gaveston again, and eventually capture and execute him. When Edward hears of Gaveston's death he mourns heart rendingly just like a widowin presence of the deadbody of her husband:

“...I shall never see

My lovely Piers, my Gaveston again.” (III.ii. 7-8)

Edward now seeks comfort in a new favourite, Spencer, making him Earl of Gloucester and Lord Chamberlaine- 'Despite of times, despite of enemies'. There is hubris in this, and yet almost at once Edward wins his first success in the play: he defeats the barons and takes them captive. Yet he ensures Mortimer is just imprisoned instead of beheading. This was a weak moment when Edward II shows his reciprocated love towards Mortimer, of whom he suspects a dalliance with Isabella and spares him, - Go, take that haughty Mortimer to the Tower; / There see him safe bestowed; and for the rest, / Do speedy execution on them all. $\square$ (III, iii, 276278). The survival of both Edward II and Mortimer in the play is dependent on each other, Marlowe hence brilliantly ties them together, for the murder of one, will lead to the death of another.

Of course it is Mortimer who finally wins and intrigues the death plot of Edward II. Even here we find a touching sense of homoeroticism. The anal assassinator Lightborn employed by Mortimer specifically boasts of a multitude of assassination methods guarantees to achieve a purpose highly phallic in nature. He offers Mortimer a brief course of his covert techniques:

"I learned in Naples how to poison flowers;

To strangle with a lawn thrust down the throat;

To pierce the windpipe with a needle's point;

Or, whilst one is asleep, to take a quill

And blow a little powder in his ears;

Or open his mouth, and pour quicksilver down.

But yet I have a braver way than these. "(V. iv. 31-37)

Lightborn, Edward's executioner and a political extension of Mortimer's stolen power, overmasters and sodomizes his prostrate sovereign by reaming him with a red-hot spit. Sexual justice is provided and obtained while subjecting Edward II to his death, social justice is also achieved as all the Megalomaniac perpetrators are sent to the gallows.

Marlowe's play very beautifully offers a character Edward II and his alter ego Mortimer, both on extreme ends but tied very closely to each other, which obviously comes out as a fact when Mortimer murders Edward II and thereby causing his own doom. They both are attached to an imaginary cord of life, which allows them to survive, conveying the intention of Marlowe's mind who weaves their homoerotic enmity and union. But the vision thus projected is profoundly pessimistic. Marlowe's embedded dialectic between emotional selffulfilment and patriotic responsibility, between identity as a lover and identity as a king, erects an impasse that only death can break. This is in fact, makes the homoerotic sense a more realistic and humanizing one. By humanizing homosexuality, I feel, Marlowe also implicitly attacks the prevalent religious, legal, and popular attitudes of his day. And by doing so he might have advocated his own homoeroticism. Infact rumors persist that Marlowe was a practicing homosexual during his time in London. The claims supporting this are spurious, however. The only statement Marlowe was supposed to have made on the issue was, "All they who love not tobacco and boys are fools." . The strong homosexual themes in Marlowe's plays Dido, and Queen of Carthage may also denote it.

It is, finally, difficult to overstate the significance of Edward II in the history of literary depictions of homosexuality, yet it is equally important not to regard the play as simply a liberal defense of sexual freedom. 
Although Marlowe refuses to condemn homosexuality, he complicates the relationships of Edward and his lovers, presenting them ambiguously rather than merely sympathetically; they are tainted with the self-seeking that characterizes everyone in the play, including the reactionary, class-conscious barons. In fact, the hypocrisy of morality-mongering of all kinds is systematically exposed and unmercifully parodied in the play. It stands out as perhaps the only relationship(Edward- Gaveston) unlike the relationship between Edward II and Mortimer, that doesn't involve the kind of political backstabbing and double-talking scheming that permeates this play. Around each other, Edward and Gaveston are honest and painfully human. In portraying them so, Marlowe makes an implied defense of alternative sexualities through theater, especially with regard to the act of gendercrossing on stage.

\section{Works Cited}

[1]. Cady, J. "Masculine Love", Renaissance Writing and The "New Invention" of Homosexuality. Summer, C. J. ed. Homosexuality in Renaissance and Enlightenment England: Literary Representation in Historical Context. New York, London, Norwood (Australia): The Haworth Press, Inc., 1992.

[2]. Marlowe, Christopher. Edward The Second (1591-2). Ed. R. G. Lunt. Book Land. D.K. Fine Art Press, 2004. Print.

[3]. Whitney, Geoffrey. A Choice Of Emlemes And Other Devices.

[4]. Bredbeck, G. W.Sodomy And Interpretation, Marlowe To Milton. (Cornell University Press, 1991.)

[5]. Cady, J. "Masculine Love", Renaissance Writing and The "New Invention" of Homosexuality. Summer, C. J. ed. Homosexuality in Renaissance and Enlightenment England: Literary Representation in Historical Context. New York, London, Norwood (Australia): The Haworth Press, Inc., 1992.

[6]. Goldberg, Jonathan. Sodometries. Renaissance Texts - Modern Sexualities. Stanford, CA: Stanford University Press, 1977.

[7]. Peres, Gelson. "Homophobia in Marlowe's Edward II." Ilha do Desterro 34 (1998): 105-112.

[8]. Ramji Lall. Christopher Marlowe: Edward the Second (New Delhi: Rama Brothers India Pvt. Ltd., 2005), p. 112.

[9]. A.K. Khullar. Christopher Marlowe's Edward the Second.

[10]. Sterling, Eric. The Movement Towards Subversion. The English History Play from Skelton to Shakespeare. Lanham, New York, London: University Press of America, Inc., 1996.

[11]. Sedgwick, Eve Kosofsky. Between Men. English Literature and Male Homosocial Desire. New York: Columbia University Press, 1985 .

[12]. Bray, Alan. 1994: "Homosexuality and the Signs of Male Friendship in Elizabethan England.” J. Goldberg, ed. 1994

[13]. Pistotnik, Vesna. 1990: “Edward II: A Scandal of Language.” Language and Style. 